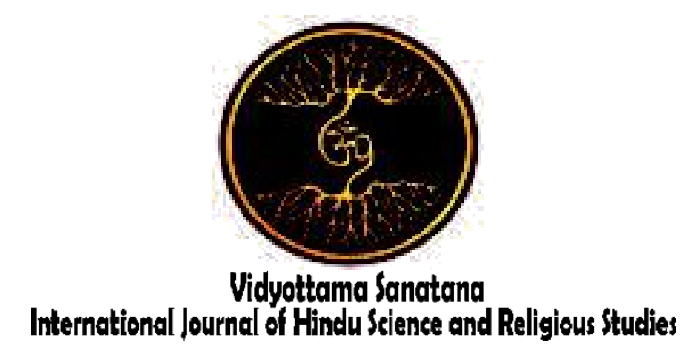

Vol. 3 No. 1 May 2019

\title{
MAP OF THE IMPLEMENTATION OF THE SCHOOL LITERACY MOVEMENT ON HINDUISM AT PRIMARY SCHOOL IN BADUNG REGENCY
}

\author{
By: \\ I Made Alit Mariana, Ni Made Anggreni \\ Institut Hindu Dharma Negeri Denpasar \\ E-mail : alit_mariana@ihdn.ac.id, madeanggreni@ihdn.ac.id
}

\begin{tabular}{|l|l|l|}
\hline Received: January 3, 2019 & Accepted: May 12, 2019 & Published: May 31, 2019 \\
\hline
\end{tabular}

\begin{abstract}
This study was conducted against of an alarming social phenomenon intolerant of differences, includes: the actions and words that, information on social media and various counter-productive behaviors. Almost in all aspects of life, the attitude of intolerance from one another appears, on the highway - the road user grabs the bow, in the place of the crowd in social action, up to the meeting room is shown to be unprepared to be different from one others. In short, it is not tolerant of pluralism. This concern, triggered the need to be redefined about the implementation of the teachings of goodness (characters building), especially for students. Various efforts have been made to define good behavior through education, including a national seminar on moral literacy in human development through education and movement on literacy formation.

Research on elementary school teachers, school principals, and school supervisors in four sub-districts in Badung regency, the method for obtaining data is through questionnaires, focus group discussions, and observations to elementary schools. The tendency to decrease the intensity of School Literacy Movement (SLM) implementation Hinduism for the habituation, development, and learning stages, both information from the Teacher (T), School Principle (SP) and School Supervisor (SS). Implementing SLM Hinduism include: reading 15 minutes at the beginning of learning, discussing books and reading together, and reading the lesson enrichment part. Programs that still need to be improved include: reading Hinduism books are relatively lacking due to difficulties in obtaining books on Hinduism and making info-graphic from reading as an effort to facilitate the building of the meaning of Hinduism reading.
\end{abstract}


As a conclusion, SLM Hinduism by Elementary Schools in Badung Regency, well implemented tends to be very good, reaching 3.6 for scale 4 . The decrease occurred from the habituation stage (3.7), development (3.6), to the learning stage (3.5). This shows that SLM Hinduism implementation has not been optimally, especially at the learning stage. Implementation of habituation stage, "the movement of reading 15 minutes of non-lesson books before the lesson". The implementation of the learning stage that has not been achieved is about "choosing enrichment books and Hinduism material and using Hinduism facilities as well as enrichment books to creatively write opinions based on reading material synthesized with other relevant disciplines as one facet literate in the Hinduism".

Keywords: SLM - School Literacy Movement, Hindu Literacy, habituation stage, development stage, learning stage, Teacher, School Principle, School Suervisor

\section{Introduction}

Social phenomena are currently found in different perspectives on various social issues, tend to be found in statements that are intolerant between communities and between individuals. the flood of information from social media and the existence of various counter-productive behaviors in social phenomena in our environment is also worrying for someone who care about the integrity of the nation and state. Almost in all aspects of life, an attitude of intolerance from one another begins to emerge, on the road traffic seizes the direction of each other, in the place of the crowd in the social action, until the meeting room is unprepared to differ from one another.

This concern, triggering need to be redefined about the implementation of good teachings, especially for students by involving all components of society. Various attempts were made to define good behavior. The diversity of people's beliefs in the context of spirituality and religiosity is undeniable and is a necessity in this life, so that in every corner of our residence we will find religious diversity. Religious pluralism in question is the recognition of the existence of other religions by followers of different religions in social life, and also actively involved in understanding differences and understanding in order to achieve harmony within the framework of the NKRI.

Moral literacy is the meeting point, the universal space of truth for all differences from all groups of people, who live side by side through social media, to be able to coexist in harmony. Moral literacy as a capital of universal truth, needs to be developed together and formulated dynamically by internalizing local wisdom and other predictors. Of course this effort requires the courage to let go of the ownership of the truth and continually build awareness to reduce judgment in the deepest heart, so that harmony appears. Harmony to divine beliefs, harmony with fellow humans, harmony with nature - TRI HIta Karana. We realize that this is easy to say, and difficult to implement, but what is difficult is not being implemented if you have strong desires and are carried out together. Joint consensus as a form of glorifying civilization in the era of globalisation is very important to find discourse space as a constructive effort to voice clarity of heart and mind together from a different perspective.

\section{Methods}

This research took place in four kecamatan: Abian Semal, Mengwi, Kuta, and Kuta Utara; is a qualitative research, post-facto, describing implementing SLM Hinduism as an effort to build Hindu literacy in elementary schools. The approach used taking data: FGD (focus group discussion), questionnaire with attitude scale, and observation to school. Research respondents included: Teachers, Principals, and School Supervisors on SLM implementation in the Hinduism. The development of research instruments in the form of an attitude scale 
questionnaire refers to Edwards, Allen L. (1957) Techniques of Attitude Scale Construction, and the procedure for conducting qualitative research in order to obtain adequate information refers to Chaedar A. Alwasilah (2002), Basically Qualitative: Basics of Designing and Conducting Qualitative Research. The development of the contents of the research instrument by referring to Juandanilsyah (2016) Guide to School Literacy movements in Primary Schools.

Opinions of respondents were analyzed by comparing between groups of respondents (T, SP, and SS) from each stage of SLM implementation in the Hinduism. Instrument used to map the implementation of the SLM in Hinduism, with the grid as follows. The habitual stage: (a) Read the book for 15 minutes before the lesson begins; (b) Functioning the school's physical environment to foster interest in reading; and (c) Involving the community outside the school for 15 minutes of activities to read and develop literacy facilities, as well as library collection books. The Development stage: (d) Read non-lesson books; (e) Activating Background Knowledge; (f) Establishment of the School Literacy Team. The Learning stage: (g) Various ways of reading to understand meaning and can build understanding; (h) Choosing a book on enriching subject matter; (i) Using enrichment books for creative writing.

\section{Result And Discussion}

When we fail to identify universal parameters in interacting with other nations, and neglect to implement them at the practical level, they will undoubtedly be counter-productive towards the association of a community (national, international). To findout universal parameters needed literacy in order to be able to build value. Juandanilsyah (2016: 3) states the notion of School Literacy in the context of School Literacy Movement (SLM) is the ability to access, understand, and use something intelligently through various activities, including reading, seeing, listening, writing, and / or speaking. Meanwhile, GLS is an overall effort to make schools as learning organizations whose citizens are literate throughout life through public involvement.

Doni Koesoema A. (2017: 44), states Literacy is the basis of the lifelong learning process, is a skill for personal and social development; literacy is the ability to understand, use and create various forms of information for self and social development in the context of building a better life, referring to the ability to read, write and use various media as a source of critical and creative learning. Literacy needed in the $21 \mathrm{st}$ century according to C. Fadel (2008) includes information literacy, media literacy, and ICT literacy.

Eithne Kennedy (2012), states that there are six aspects in assessing literacy: assessment rules for learning and assessment of children's learning outcomes; literacy aspects of the beginning of the year; formal and informal to assess literacy; literacy assessment framework; assessment of children whose English is an additional language; and approaches to using assessment data to inform planning at the teacher and school level.

The challenge of education about the synergy and responsibility of schools, parents, and society, in accordance with the results of mapping of character building in schools in the book Morphology The practice of character building in Bali this component occupies the bottom then others (Alit Mariana, IM. 2015: 92). This means that there is a very important program that allows the development of synergies and responsibilities of schools, parents, and the community to be a greater concern on character building.

The School Literacy Movement is a government policy in improving the quality of education. SLM in its implementation is made into three stages, namely habituation, development, and learning. The implementation phase was developed to pay attention to the intellectual development of students. In this study, the three stages are defined as follows. The importance of 
building literacy is also expressed by the need for student activity in learning. Alit Mariana, IM (2018: 30) states that learning is not just recording and memorizing, but an experienced process, so students must be actively encouraged to carry out certain activities, find and discover facts themselves, and formulated infferency into fact-based explanations. The activities carried out by these students will enable the activation of the post knowledge and physically manage various tools to build skills.

The Habituation stage, fosters interest in reading reading books about Hinduism, consisting of (a) Reading books for 15 minutes before the lesson begins (Reading story books and reading enrichment books), (b) Enabling the physical environment of the school to develop interest in reading - (read, school libraries and pelangkiran, Padmasana and Pelinggih Penunggu Karang), and (c) Involving communities outside the school activities 15 minutes reading and developing literacy facilities, as well as library collection books (caring community schools, atmosphere and adequate reading rooms, good Hindu reading books)

The Development phase, through fostering interest, facilities, reviewing, and appreciating reading about Hinduism for school people and society, was elaborated into: (d) Reading non-lesson books relating to Hinduism, (e) Enabling Background Knowledge, (f) Formation School Literacy Team.

At the learning stage, maintaining interest in reading, and improving skills through studying enrichment books and textbooks on Hinduism, namely: (g) Various ways to read Hindu books. (h) Choose books for enriching subject matter and Hinduism. (i) Use enrichment books to creatively write opinions based on reading material.

Tjokorda Oka Artha Ardana Sukawati (2017: 8) in his book "Taksu: Behind Bali Tourism Development" states that cultural tourism is based on Balinese culture and
Hinduism, so it is necessary to explore Hinduistic spatial planning. The management of Hinduistic spatial planning needs to be implemented in schools as an educational entity. Schools as agents of change and agents of knowledge should be able to follow the Hindusitis spatial plan. The concept of building Bali tourism is called Padma Mandala, containing Tri Hita Karana, Tri Mandala, and Dewata Nawa Sanga.

Teacher's opinion on the implementation of SLM in Hinduism is like the graph 1 .

The implementation map of the School Literacy Movement in the Hinduism field can be described as four features, namely: maps according to the Teacher, maps according to the School Principal, Maps according to School Supervisors, and an overview or aggregate. According to the teacher, the implementation of SLM was described: the habituation stage reached 3.7; the development stage reaches 3.5; and the learning stage reaches 3.5.

The teacher believes that the implementation of SLM The habituation phase through growing interest in reading reading books about Hinduism in the school environment is 3.7. The teacher believes that at this stage of habituation it has been implemented tend to be very good, meaning that the habituation stage has been done even though it is not perfect. The indicator for the habituation stage is the aspect of reading the book for 15 minutes before the lesson begins using the school's physical environment. Of the three indicators of refraction indicator, the functioning of the school's physical environment to foster interest in reading occupies the highest position, 3.8 relatively high. But, in terms of the use of the physical environment, Padmasana as a means of building Hindu literacy, not not have been used optimally. And, lack of using enrichment books (Hinduism) for creative writing. 


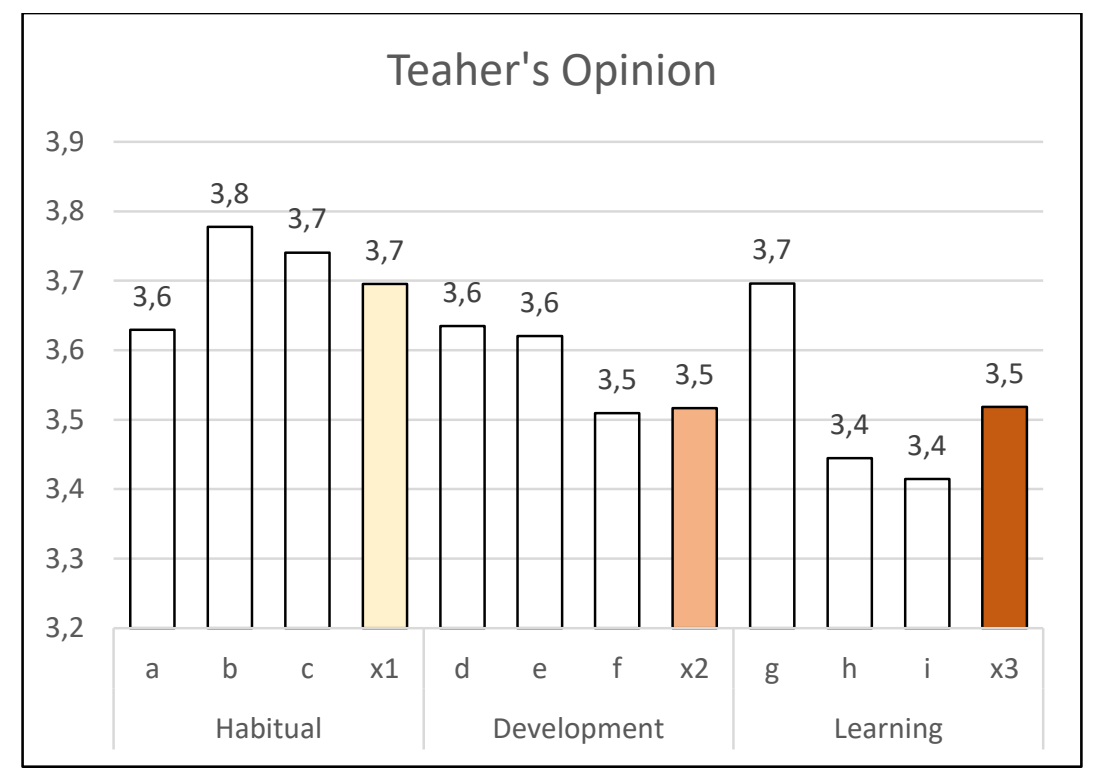

Grafik 1. Teacher's opinions in each stage and indicators

The three aspects of SLM the highest achievement is the Habituation implementation in primary school are the stage and the lowest achievement is the highest in the implementation index at the Learning stage. Implementation at the Habit Stage, and the lowest is the Learning highest level of habituation lies in the Stage.

School Principle's opinion on the implementation of SLM in Hinduism is like the graph 2.

Among the three stages of SLM in Hinduism, according to the School Principal indicator of Reading the book 15 minutes before learning begins. The indicator at the lowest learning stage is Choosing a book on enriching Hinduism subject matter and the Using enrichment books for creative writing on Hinduism.

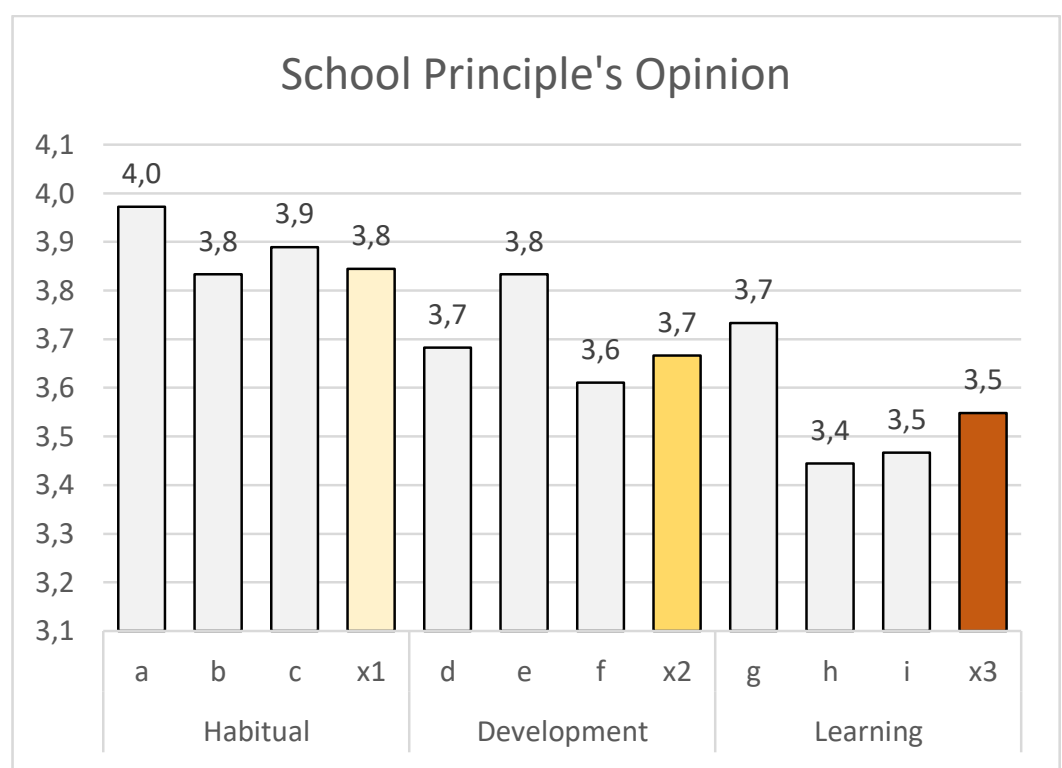

Grafik 2 School Principle's opinions in each stage and indicators 
School Supervisor's opinion on the implementation of SLM in Hinduism is like the graph 3 .

Among the three stages of SLM in Hinduism, according to the School Supervisor the simillar achievement is the Habituation stage and the Development stage - higher then third stage. The lowest achievement is the Learning stage.
Implementation at the highest level of habituation lies in the indicator of Reading the book 15 minutes before learning begins. Implementation at the highest level of habituation lies in the Activating Background Knowledge. The indicator at the lowest learning stage is Choosing a book on enriching Hinduism subject matter.

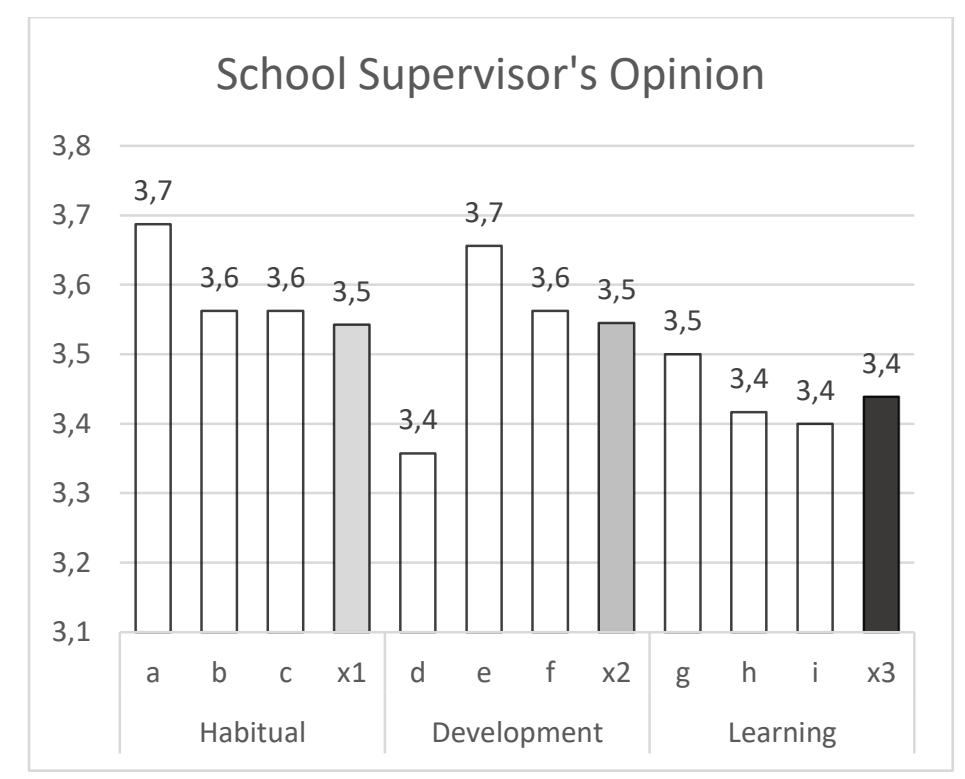

Grafik 3. School Supervisor's opinions in each stage and indicators

Teachers, School Principle, and School Supervisor's opinion on the implementation of SLM in Hinduism is like the graph 4.

Among the three stages of SLM in Hinduism, according to the all respondent group the highest achievement is the Habituation stage and the lowest achievement is the Learning stage. All group respondent that says the Reading the book 15 minutes before learning begins indicator have been done. Almost all respondent group claim that quite deficult to find Hinduism book for enrichment and for student textbook.

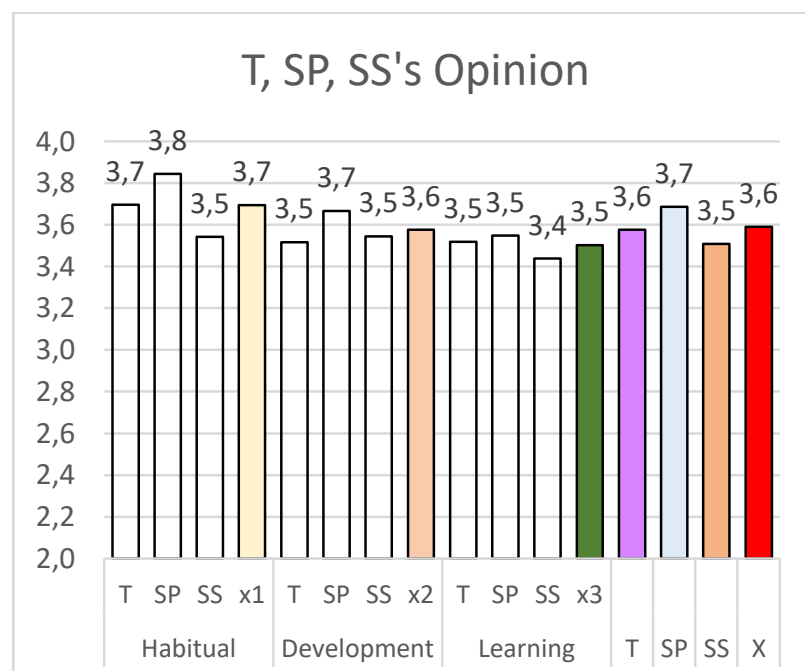

Grafik 4. Teacher, School Principle, and School Supervisor's opinions in each stage and indicators 
Each stage of SLM in Hinduism is elaborated into an indicator and each indicator is described as a sub-indicator which then becomes a statement in the questionnaire. In the analysis, the average for each indicator and sub-indicator is made, as in the presentation of the graph above. Data on the implementation of SLM in the Hinduism which is an aggregate of the three groups of respondents, were analyzed based on the group of respondents; analyzed based on the SLM stage; and also analyzed indicators and sub-indicators of the research instrument.

The index implementation of SLM in Hinduism is compared among Teachers, School Principle, and School Supervisor, School Principle's opinion the highest implementation of SLM in Hinduism (3.7 SP) and School Supervisor's opinion the lowest (3.5- Graph 4: SS) see Graph 4 Opinions of Teachers, School Principals, and School Supervisor's on SLM in Hinduism Implementation in elementary schools. There are different perceptions in seeing SLM implementation among Teachers, School Principle, and School Supervisor; but all still ranges tend to be very good (3.6). The School Principal's perception of the implementation of SLM Hinduism was the highest, and the lowest was the perception of the implementation of the SLM Hinduism is School Supervisor.

All respondent groups perceive that the tendency to decline in implementation starts from the stage of habituation, development, to learning. This indicates that the implementation of SLM in Hinduism is not optimal yet, because at the learning stage it is peak to have a high implementation index or at least the same as the other stage. At the Learning Stage, there are important processes haven for the student informatioan processing with meaningfull learning.

We analyze based on the group of respondents, Teacher's opinion (Graph 1) on aspects of the habituation stage, namely growing interest in reading books about Hinduism in the school environment is 3.7. The teacher believes that at this stage of habituation it has been implemented, tends to be very good, meaning that the habituation stage has been done even though it is not perfect. The habituation stage is in the aspect of reading a book for 15 minutes before the lesson begins. From the three indicators of habituation stage, the indicator "functioning of the school's physical environment to foster interest in reading occupies" the highest position, 3.8. But after being traced about the use of the physical environment, in Padmasana - as one important area according Tri Mandala conception, as a means of building Hindu literacy, it has not functioned much.

Based on the respondent group, the School Principal's perception (Graph 2) shows a downward trend starting from the Habituation Stage, Development Stage, to the Learning stage, however the overall achievement of Hinduism SLM implementation is still categorized as very good. The good thing to do at the Habituation stage is "read the non-text book 15 minutes before the lesson begins. For The Development phase, indicator which as important homework to be improve is (f) Formation School Literacy Team. The thing that still needs to be improved at the Learning stage is "choosing enrichment books and Hindu textbooks".

School Supervisor (Graph 3) respondent groups, perceptions about the implementation of SLM Hinduism found a decline starting from the Habituation Phase, Development Stage, to the Learning stage. As with other groups of respondents, the School Supervisor also stated that the achievement of the Learning Stage was the lowest compared to the others stage. The lowest indicator is (h) Choose books for enriching subject matters and (i) Use enrichment books to creatively write opinions based on reading material; especially about textbooks and enrichment books about Hinduism.

\section{Conclusion}

The general conclusion that can be formulated is that the implementation of 
SLM at for all kecamatan in Badung District has been implemented well, tends to be very good, although there is a decrease in implementation from the habituation stage, the development stage, to the learning stage. But if analysed it based on the Hinduism aspect, it still needs a lot of effort so that Hindu literacy can be built on elementary school students.

All respondent groups stated that reading a book 15 minutes before the lesson began was done very well, and students were very enthusiastic about carrying out it. All respondent groups stated that it was difficult to find reading books about Hinduism, thus suggesting that there were stake holders who could help elucidated them (Perbowosari, 2018).

The difficulty experienced in implementing SLM in Hinduism in elementary schools is in the Learning Stage, so that it requires mentoring and competent attendees or instructor to implement it effectively.

School arrangements that have Hindu values (metaksu) are in accordance with the Tri Bhuwana concept, so that the implementation of the SLM, Learning stage is more effective, very necessary. Padmasana as the center of the sacred area is very important as a means of building Hindu literacy. In terms of establishing Hindu literacy, besides to having students read textbooks and enrichment, practicing directly has a leverage to build competence and literacy in the field of Hinduism.

\section{References}

Alit Mariana, Made. 2015. Morfologi Praktek Penumbuhan Budi Pekerti di Bali. LPMP Provinsi Bali, Kemdikbud.

Alit Mariana, I Made. 2018. Pengantar Perencanaan Pembelajaran di Sekolah Dasar. Penerbit LPMP Provinsi Bali,
Denpasar.

Bransford, John D., et al. 2000. How People learn: Brain, Mind, Experience, and School. National Academy Press. Washington, DC.

Chaedar A. Alwasilah. 2002. Pokoknya Kualitatif: Dasar-dasar Merancang dan Melakukan Penelitian Kualitatif. PT. Pustaka Jaya dengan Pusat Studi Sunda. Jl. Karawitan No. 46, Bandung 40264.

Cruickshank, D.R; D.B. Jenkins; K.K. Metcalf. 2006. The Act of Teaching. Four edition. Mc. Grow-Hill Higher education. Boston.

Edwards, Allen L. 1957. Techniques of Attitude Scale Construction. AppletonCentury Crofts. Inc. USA New York.

Helmenstine, Anne Marie. 6 Steps of the Scientific

Method.

https://www.thoughtco.com/steps-ofthe-scientific-method-p2-606045.

Juandanilsyah. 2016. Panduan gerakan Literasi Sekolah di Sekolah Dasar. Ditjen Pendidikan Dasar dan Menengah, Kemdikbud.

Kennedy, Eithne dkk. 2012. Literacy in Early Childhood and Primary Education, (3-8 years) report. The University of Sheffield.

Titib, I Made. 1996. Veda: Sabda Suci Pedoman Praktis Kehidupan. Penerbit Paramita. Surabaya.

Oka Artha Ardana Sukawati, Tjokorda. 2017. Taksu: di Balik Pembangunan Pariwisata Bali. PT. Percetakan Bali, jl. Gajah Mada I No. 1 Denpasar, Bali.

Perbowosari, H. (2018). Parenting Models In Building The Religious Characters Of Children. Vidyottama Sanatana: International Journal of Hindu Science and Religious Studies, 2(1), 39-48. 